\title{
Primary School Student Online Video Competition Model to Improve Six Steps Handwashing Ability to Prevent Upper Tract Infection
}

\author{
Titiek Hidayati ${ }^{1{ }^{*}}$ Suryanto $^{2}$
}

\author{
${ }^{1}$ Department of Epidemiology, Family Medicine and Public Health, Faculty of Medicine and Health Sciences, Muhammadiyah \\ University of Yogyakarta, Yogyakarta, Indonesia \\ ${ }^{2}$ The Faculty of Language Education (FPB) Universitas Muhammadiyah Yogyakarta (UMY), Yogyakarta, Indonesia \\ ${ }^{*}$ Corresponding author. Email: hidayatifkumy@yahoo.co.id
}

\begin{abstract}
The prevalence of upper tract infection / ARI in primary schools is $15 \%$ in 2019. Currently, upper respiratory infections cause most students to be absent from school compared to other disease factors. One of the most important causes of ARI is hand hygiene; therefore, washing hands using soap is the most critical effort to reduce ARI's prevalence in primary schools. This study aimed to determine the effect of the online video competition model on elementary school students to improve the ability to wash hands in 6 steps. The research design was an experimental control group. The number of research subjects was 30 students for the treatment group and 30 students for the untreated group. The length of the study is one month. The results showed that students who took part in online competitions experienced a significant increase in knowledge, attitudes, and behavior towards washing hands using soap. The research results on the intervention video competition as an educational medium about washing hands six steps compared to the control group. The video competition improves the ability to do handwashing in 6 steps, namely by doing, seeing, and listening.
\end{abstract}

Keywords: Video competition, Hand washing, student, infection

\section{INTRODUCTION}

WHO estimates that upper tract infection incidence is 40 - 80 times higher in developing countries than in developed countries. Acute respiratory infections occupy the top position in the ten most common health canters in Indonesia, besides acute respiratory infections, ranking the third largest cause of death in the world $(7.1 \%)$ and the first cause of death in developing countries $(11.2 \%)$ or in other countries. with middle to lower-income per capita. Indonesia ranks sixth after India, China, Pakistan, Bangladesh, and Nigeria [1]. Vulnerable groups, namely infants, children, and the elderly, have a high mortality rate. The incidence of acute respiratory infections in children increases in families with indoor air pollution conditions $[2,3,4]$.

Efforts to prevent respiratory infections have been widely researched, such as oral vitamin $\mathrm{D}$, to avoid recurrent pneumonia in toddlers [5]. The use of catechins classified as flavanols found in green tea Camellia sinensis can protect against respiratory tract infections [6,7]. Green tea catechins have antiviral and antibacterial effects inhibiting influenza virus replication in cell culture and reducing virus titter $[8,9,10]$. Another preventive measure is vitamin $\mathrm{C}$, this vitamin for the prevention of acute respiratory infections. In previous studies, it was only effective in children under six years of age [11]. Another prevention is providing health education to the public regarding clean and healthy living habits [12]. Personal hygiene and protection are the most important to prevent the spread of respiratory infections, such as washing hands and wearing masks [13]. One of the problems in educational efforts in primary school children is the problem of media and language. However, in information technology, language, and media, barriers to education have decreased.

The promotion of health behaviors and high compliance are efforts to prevent respiratory infections [14]. Health education has used a lot of audio-visual media assistance because it can increase awareness of healthy living habits and be witnessed by various communities [15]. A wellpackaged video makes it easier for the public to receive the information conveyed and affects a person's intention to carry out health behavior. Covid-19 education uses videos as health education to the general public through internet applications and websites to help people who have experienced trauma due to Covid-19 and health workers in mental management [16].

Health education about a clean and healthy lifestyle is an effort to reduce respiratory infections in elementary school students in Indonesia. Using audio-visual media as the Media for health education regarding clean and healthy living habits for elementary school students is unknown. The habit of washing hands with six stages is one of the essential hygiene and healthy living habits for elementary school students. This study aims to determine the Effectiveness of the audio-visual competition for health education media to improve the practice of washing hands in 6 stages in elementary school students. 


\section{METHOD}

This research is a quantitative study using a quasiexperimental design with pre-test and post-test control group design. The results were obtained by comparing any changes before and after implementing the handwashing educational video competition model and education given to the research group. The study has received Ethical Clearance approval from the Ethical Commission of the Faculty of Medicine and Health Sciences, Muhammadiyah University of Yogyakarta. The population in this study were students in a junior high school in Bantul, Yogyakarta. The technique of selecting samples is done by using the purposive sampling technique. Researchers determining the selection can choose the subjects to be the sample based on the specified criteria to facilitate data collection. In this study, the model had hand pond tools or understood technology and information according to inclusion and exclusion criteria. Based on the calculation of the number of samples of the statistic model and after fulfilling the inclusion and exclusion criteria, the number of subjects was 43 students consisting of 25 treatments and 18 students as controls. Inclusion criteria are Islamic junior high school students in Bantul, aged 10-19 years, willing to be research subjects, have access to the internet, mostly the Google Classroom communication platform, and YouTube.

Meanwhile, the exclusion criteria were not in good health; students followed the preliminary stages when the research was conducted. The intervention as an independent variable is a video competition model after students are given education about washing hands, hygiene, healthy living habits, making videos four times for one month, and holding the competition after the instruction is over. The intervention's effect is known by looking at the dependent variable, namely the students' knowledge and attitudes, as measured using a questionnaire. Data were collected twice, namely before intervention in the form of handwashing education and after an intervention. Measurements are made using a numerical scale for the knowledge questionnaire and an ordinal or stratified scale for the attitude questionnaire; questionnaire filling is done via a google form, sent to students. The instruments used in this study were hand washing educational videos, google form questionnaire instruments, cell phones, or laptops.

\section{RESULTS AND DISCUSSION}

Based on table 1, it is found that the characteristics are evenly distributed in the intervention and control groups. This condition indicates that students' parameters of age, sex, and biological condition are evenly distributed in the two groups or that these parameters do not become confounding variables in the study.
Table 1. Characteristics of age, sex of students in the intervention and control groups before video competitions, and counseling were held.

\begin{tabular}{|l|l|l|l|l|}
\hline No & & \multicolumn{2}{|c|}{ Group } & \multirow{2}{*}{} \\
\cline { 3 - 4 } & Characteristics & Intervention & Control & P \\
\hline 1 & Age & $13.3 \pm 2.6$ & $15.2 \pm 3.3$ & 0.16 \\
\hline 2 & a. Male & 18 & 13 & \multirow{2}{*}{0.48} \\
\hline 3 & b. Female & 7 & 5 & \\
\hline 4 & Weight & $40.3 \pm 3.7$ & $44.2 \pm 5.7$ & 0.37 \\
\hline
\end{tabular}

Table 2. Differences in students' knowledge and attitudes in the intervention and control groups among students after the video competition

\begin{tabular}{|l|l|l|l|l|l|}
\hline Variable & & \multicolumn{2}{|c|}{ Group } & $\begin{array}{l}\text { Nilai } \\
\text { P }\end{array}$ & CI \\
\cline { 2 - 6 } & & $\begin{array}{l}\text { Interventi } \\
\text { on }\end{array}$ & Control & & \\
\hline \multirow{2}{*}{$\begin{array}{l}\text { Knowled } \\
\text { ge }\end{array}$} & Pre-test & $12.6 \pm 0.8$ & $12.6 \pm 0.6$ & 1.00 & $0.8-1.9$ \\
\cline { 2 - 6 } & $\begin{array}{l}\text { Post- } \\
\text { test }\end{array}$ & $18.1 \pm 0.9$ & $13.0 \pm 0.7$ & 0.00 & $4.2-5.9$ \\
\cline { 2 - 6 } & Delta & $5.5 \pm 1.1$ & $0.4 \pm 0.6$ & 0.00 & $4.1-6.1$ \\
\hline Attitude & Pre-test & $12.6 \pm 0.7$ & $12.6 \pm 0.6$ & 1.00 & $0.7-0.7$ \\
\cline { 2 - 6 } & $\begin{array}{l}\text { Post- } \\
\text { test }\end{array}$ & $17.9 \pm 1.4$ & $12.6 \pm 0.9$ & 0.00 & $3.9-6.7$ \\
\cline { 2 - 6 } & Delta & $5.3 \pm 1.6$ & $0.0 \pm 0.7$ & 0.00 & $3.8-6.8$ \\
\hline
\end{tabular}

Based on table 2, there was no significant difference between knowledge and attitudes at pre-test than knowledge and perspectives at the post-test in the control group. This condition can happen because there is no video and educational competition model carried out between the pretest and post-test, so there is no significant effect on knowledge and attitudes.

These conditions are different in the intervention group. Table 2 shows that the intervention group has a significant difference between knowledge and attitudes during the pretest/before the intervention compared to knowledge and attitudes at the post-test or after the intervention. The video and educational competition model carried out between the pre-test and post-test has a significant effect on increasing students' knowledge and attitudes. Videos influence to increase knowledge, attitudes, and behavior.

Education through video offers a way to educate someone in a standardized manner [17]. Education through video is a complement to satisfactory disclosure, such as the ease of remembering [18], understanding[19], increasing short-term knowledge, and maintaining satisfaction consistently[20]. Video is a potential alternative media that can minimize human interference [21].

In dengue fever case research, the use of audio-visual media is appropriate to change family behavior, including attitudes and measures to prevent dengue fever[22]. Video 'Brain Breaks' in diabetes patients became an effective intervention to motivate patients to increase their physical activity from two groups: the intervention and control groups, which showed significant differences after the intervention [23]. Research on the Effectiveness of the video "A New You, That Who," namely adolescent health education videos about puberty, menstruation, and 
reproductive anatomy, is a useful free tool in providing essential knowledge to adolescents about reproductive health[24].

Health information is currently very easily accessible via YouTube, and recently in China, it has started trying to use the TikTok app to foster engagement between health workers and citizens to communicate health information [25]. Previous studies have reviewed several health videos including smoking cessation[26], tobacco use[27], myocardial infarction[28], cardiopulmonary resuscitation[29], bone tumours[30], vaccinations[31], pain management during immunization[32], influenza H5N1[33], HPV[34], new-born blood tests [35], cancer pain care management[36], arthritis [37], and neuroscience [38].

The benefits of using video in the world of health are many; apart from increasing knowledge, changing the behavior of a person or group, measuring the heart rate of fish embryos[39], videos are also used in forging partnerships[40] and impacting policy decisions[41]. The use of video for education has become popular in health [42], in medical anatomy education to improve students' grades[43]. The use of video must consider the quality of the content presented, and adjustments are required so that the information conveyed through the video can be accurate [44]. The footage provides short-term and long-term behavior change; previous studies found that video education effectively maintains smoking cessation.

\section{CONCLUSION}

Based on the results of research and discussion, it is known that the competition for making health education audio-visuals about the six stages of washing hands for elementary school students can improve a clean and healthy lifestyle, especially in the habit of washing hands.

\section{AUTHORS' CONTRIBUTIONS}

$\mathrm{TH}$ and $\mathrm{S}$ contributed equally to the research design, data collection, data processing, analysis, writing draft publications, and proofreading.

\section{ACKNOWLEDGMENTS}

The researcher gave appreciation and gratitude to LPPM UMY for financial assistance for the implementation of this research activity. We would like to thank all students who have been willing to participate and their guardians and school managers who have given permission and support for this activity.

\section{REFERENCES}

[1]. I. Rudan. Epidemiology and etiology of childhood pneumonia in 2010: Estimates of incidence, severe morbidity, mortality, underlying risk factors, and causative pathogens for 192 countries. J. Glob. Health 3 , (2013).
[2]. P. S. Hidayangsih., D. H. Tjandrarini., O. Nainggolan., \& N. E. W. Sukoco. The Relationship between Respiratory Infections and Healthy Homes in Children Under Five, Indonesia 2013. Media Penelit. dan Pengemb. Kesehat. 27, (2017).

[3]. T. Ferkol,. \& D. Schraufnagel. The global burden of respiratory disease. Ann. Am. Thorac. Soc. 11, 404 406 (2014).

[4]. W. K. Liu., et al. Epidemiology of acute respiratory infections in children in Guangzhou: A three-year study. PLoS One 9, (2014).

[5]. N. Singh., D. Kamble., \& N. S. Mahantshetti. Effect of Vitamin D Supplementation in the Prevention of Recurrent Pneumonia in Under-Five Children. Indian J. Pediatr. (2020) doi:10.1007/s12098-020-03244-9.

[6]. D. Furushima., et al. Prevention of acute upper respiratory infections by consuming catechins in healthcare workers: A randomized, placebo-controlled trial. Nutrients 12, 1-12 (2020).

[7]. D. D. Rio, et al. HPLC-MSN Analysis of Phenolic Compounds and Purine Alkaloids in Green and Black Tea HPLC-MS n Analysis of Phenolic Compounds and Purine. J. Agric. Food Chem. 52, 2807-2815 (2015).

[8]. P. Müller., \& K. M. Downard. Catechin inhibition of influenza neuraminidase and its molecular basis with mass spectrometry. J. Pharm. Biomed. Anal. 111, 222230 (2015).

[9]. J. M. Song., K. H. Lee., \& B. L. Seong. Antiviral effect of catechins in green tea on influenza virus. Antivir 68, 66-74 (2015).

[10].Y.H. Lee., Y. H. Jang., Y. S. Kim., J. Kim, \& B.L. Seong, Evaluation of green tea extract as safe personal hygiene against viral infections. J. Biol. Eng. 12, 4-13 (2018).

[11].P. Vorilhon, et al. Efficacy of vitamin $\mathrm{C}$ to prevent and treat upper respiratory tract infection. A meta-analysis in children. Eur. J. Clin. Pharmacol. 75, 303-311 (2019).

[12].G. D. Kandou., B. T. Ratag., A. F. Kalesaran, \& P. C. Kandou, The Role of Clean and Healthy Behavior in Prevention of Acute Respiratory Infection in South Tagulandang District, Sitaro Islands Regency. Adv. Heal. Sci. Res. 22, 294-297 (2020).

[13].S. Law., A. W. Leung, \& C. Xu, Severe acute respiratory syndrome (SARS) and coronavirus disease-2019 (COVID-19): From causes to preventions in Hong Kong. Int. J. Infect. Dis. 94, 156163 (2020).

[14].J. Swarthout, et al. Effects of Individual and Combined Water, Sanitation, Handwashing, and Nutritional Interventions on Child Respiratory Infections in Rural Kenya : A Cluster-Randomized Controlled Trial. 102, 1286-1295 (2020). 
[15[.S. A. McLean. Impact of viewing body image health promotion videos in adult men and women: Comparison of narrative and informational approaches. Body Image 33, 222-231 (2020).

[16].W. Li, et al. Progression of mental health services during the COVID-19 outbreak in China. Int. J. Biol. Sci. 16, 1732-1738 (2020).

[17].Y. F. Chen, et al. Effectiveness and cost-effectiveness of computer and other electronic aids for smoking cessation: A systematic review and network metaanalysis. Health Technol. Assess. (Rockv). 16, 1-205 (2012).

[18].E. A. H. Wilson, et al. Media, and memory: The efficacy of video and print materials for promoting patient education about asthma. Patient Educ. Couns. 80, 393-398 (2010).

[19].C. M. Correnti., S. C. Chen, \& B. K. Stoff, Videobased education about systemic corticosteroids enhances patient knowledge more than verbal education: A randomized controlled trial. Dermatol. Online J. 23, 0-7 (2017).

[20].D. H. K. Chow., W. H. W. Cheng., \& S.S. M. Tam, A video-based classification system for assessing locomotor skills in children. J. Sport. Sci. Med. 19, 585-595 (2020).

[21].B.M. Mulla et al. Improving Patient Knowledge of Aneuploidy Testing Using an Educational Video: A Randomized Controlled Trial. Physiol. Behav. 132, 4, (2018).

[22]. Arneliwati, Agrina \& A. P. Dewi, The Effectiveness of health education using audio-visual media on increasing family behavior in preventing dengue hemorrhagic fever (DHF). Enferm. Clin. 29, 30-33 (2019).

[23].A. Hydrus, et al. Effects of brain breaks videos on the motives for Malaysians' physical activity with type-2 diabetes mellitus. Int. J. Environ. Res. Public Health 17, 1-16 (2020).

[24].L. B. Hurwitz et al. 'A New You, That's Who': an evaluation of short videos on puberty and human reproduction. Palgrave Commun. 4, (2018).

[25].C. Zhu., X. Xu., W. Zhang., J. Chen, \& R. Evans, How health communication via tik tok makes a difference: A content analysis of tik to accounts run by Chinese provincial health committees. Int. J. Environ. Res. Public Health 17, 1-13 (2020).

[26].C. L. Backinger, et al. Youtube as a source of quitting smoking information. Tob. Control 20, 119-122 (2011).

[27].B. Freeman, \& S. Chapman, Is 'YouTube' telling or selling you something? Tobacco content on the YouTube video-sharing website. Tob. Control 16, 207-210 (2007).
[28].S. Pant, et al. Assessing the credibility of the 'youTube Approach' to the health information on acute myocardial infarction. Clin. Cardiol. 35, 281-285 (2012).

[29].K. Murugiah., A. Vallakati., K. Rajput., A. Sood, \& N. R. Challa, YouTube as a source of information on cardiopulmonary resuscitation. Resuscitation 82, 332334 (2011).

[30].N. Campbell., S. Ogilvie, \& C. Gerrand, Youtube TM as a Source of Information About Primary Bone Tumours. Bull. R. Coll. Surg. Engl. 94, 228-231 (2012).

[31].K, J. YouTube as a Source of Information on Immunization: A Content Analysis. 298, 2482-2484 (2007).

[32].D. Harrison, et al. Too many crying babies: A systematic review of pain management practices during immunizations on YouTube. BMC Pediatr. 14, 1-8 (2014).

[33].A. Pandey., N. Patni., M. Singh., A. Sood, \&G. Singh, YouTube As a Source of Information on the H1N1 Influenza Pandemic. Am. J. Prev. Med. 38, e1-e3 (2010).

[34].K. A. Ache. \& L. S. Wallace, Human Papillomavirus Vaccination Coverage on YouTube. Am. J. Prev. Med. 35, 389-392 (2008).

[35].D. Harrison. et al. A systematic review of YouTube videos on pain management during newborn blood tests. J. Neonatal Nurs. 24, 325-330 (2018).

[36].E. Wittenberg-Lyles., D. Parker Oliver., G. Demiris., J. Swarz. \& M. Rendo. YouTube as a tool for pain management with informal caregivers of cancer patients: A systematic review. J. Pain Symptom Manage. 48, 1200-1210 (2014).

[37].A. G. Singh., S. Singh. \& P. P. Singh, YouTube for information on rheumatoid arthritis - A wake-up call? J. Rheumatol. 39, 899-903 (2012).

[38].L. C. Heathcote. et al. Pain neuroscience education on youtube. PeerJ 2019, 1-22 (2019).

[39].W. K. Martin, et al. High-Throughput Video Processing of Heart Rate Responses in Multiple Wildtype Embryonic Zebrafish per Imaging Field. Sci. Rep. 9, 1-14 (2019).

[40].L. B. Wilson., B. Debaryshe., M. Singh, \& S. Taba. Early Head Start Families. Int. J. Dent. 2013, 9 (2013).

[41].A. George, et al. Comparison of video demonstrations and bedside tutorials for teaching pediatric clinical skills to large groups of medical students in resourceconstrained settings. Int. J. Educ. Technol. High. Educ. 16, (2019).

[42].A. C. W. Baldwin. et al. Through the Looking Glass: Real-Time Video Using' Smart' Technology Provides 
Enhanced Intraoperative Logistics. World J. Surg. 40, 242-244 (2016).

[43].E. Ang., S. Nabihah., B. Abu., M. Thong. \& T. Choong, Using video in medical education: What it takes to succeed. Asia Pacific Sch. 2, 15-21 (2017).

[44].B. H. Lashari. et al. YouTube as a source of patient education in idiopathic pulmonary fibrosis: a media content analysis. J. Community Hosp. Intern. Med. Perspect. 9, 98-102 (2019). 